\title{
COASTAL ADAPTATION UNDER SEA LEVEL RISE: PROTOTYPE SCALE MEASUREMENT AND MODELLING OF A DYNAMIC REVETMENT
}

\author{
Paul Bayle $^{\mathrm{a}}$, P.M.Bayle@bath.ac.uk ; Chris Blenkinsopp ${ }^{\mathrm{a}}$, c.blenkinsopp@bath.ac.uk; Gerd Masselink ${ }^{\mathrm{b}}$, \\ gerd.masselink@plymouth.ac.uk; Daniel Conley ${ }^{\mathrm{b}}$, daniel.conley@plymouth.ac.uk \\ ${ }^{a}$ WEIR - University of Bath \\ ${ }^{b}$ School of Marine Science and Engineering, University of Plymouth.
}

\section{INTRODUCTION}

A dynamic revetment is a gravel ridge constructed around the wave runup limit to mimic composite beaches which consist of a lower foreshore of sand and a backshore ridge constructed of gravel or cobbles which stabilises the upper beach and provides overtopping protection to the hinterland. These structures contrast with static coastal defence structures as they are "dynamic" and are expected to reshape under wave attack. The performance and resilience of a dynamic revetment under sea level rise (SLR) for a range of wave conditions was studied in a large scale laboratory flume. This work provided new information about the application of such structures for coastal protection in the face of a rising sea level.

\section{METHODOLOGY}

The 8-week DynaRev experiment was undertaken during summer 2017 in the GWK Large Wave Flume, Germany. The evolution of beach morphology with an incrementally rising sea level (total SLR $=0.4 \mathrm{~m}$ in steps of $0.1 \mathrm{~m}$ ) over long, multi-day test runs was measured for both a sand beach and a sand beach with a dynamic revetment. The hydrodynamics conditions were set to simulate erosive waves at high tide. Additional energetic "storm" conditions were also simulated. A large array of in situ and remotesensing instruments was deployed throughout the surf and swash zones to monitor hydro and morphodynamics, see Figure 1. These included Lidar, acoustic backscatter sensors (ABS), Multibeam Echo-Sounders, Acoustic Doppler Velocimeters (ADV) and trackable cobbles (Radio Frequency Identifier, RFID).

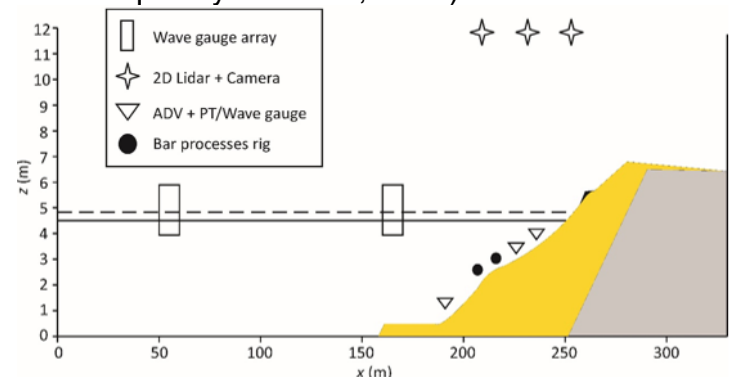

Figure 1: Schematic of the GWK Flume and the instruments position. The RFIDs are located in the revetment (small black triangle on the sub-aerial beach).

\section{DYNAMIC REVETMENT BEHAVIOR}

The final design of the dynamic revetment was based on the previous work of Komar and Allan (2009) and runup modelling. The dynamic revetment is constructed of cobbles $\left(D_{50}=66 \mathrm{~mm}\right)$, has a volume of $9.38 \mathrm{~m}^{3}$ and a crest $0.9 \mathrm{~m}$ above the still water line before SLR.

Figure 2 shows the revetment shape at different stages under multiple SLR. As the sea level rises, the toe of the structure retreats, leaving a single layer of mixed sand and cobbles. In the meantime, the front slope of the structure is reshaped under waves and steepens from $1 / 6.3$ at $\mathrm{t}=0 \mathrm{~h}$ to $1 / 2.3$ at $\mathrm{t}=38 \mathrm{~h}$.

In overall, the structure remains coherent and the cobbles place originally remain within the revetment throughout.
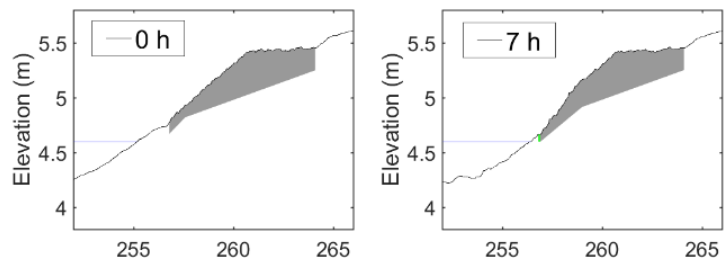

Cross-shore Distance $(\mathrm{m})$

Cross-shore Distance $(\mathrm{m})$
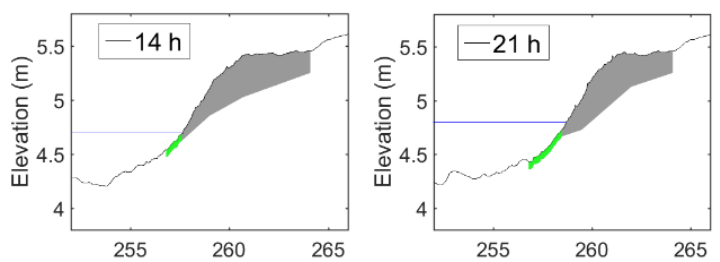

Cross-shore Distance $(\mathrm{m})$
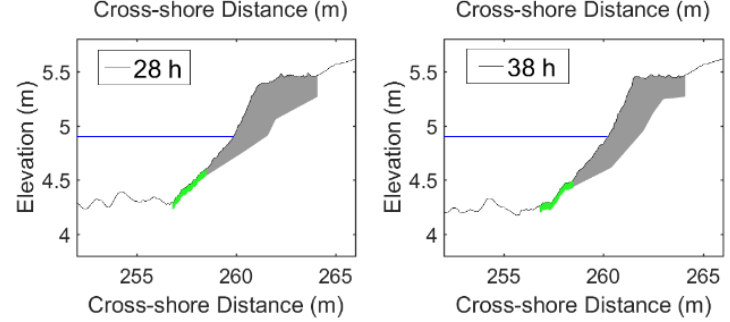

Figure 2: Evolution of the dynamic revetment at different stages. The dark grey area represents the main structure and the light green the single layer of cobble left as the revetment retreats. The profile at $t=0 \mathrm{~h}$ displays the revetment in its original shape. The profiles after $7 \mathrm{~h}, 14$ $\mathrm{h}$ and $21 \mathrm{~h}$ represent the revetment at the end of SLR 1 ( $0.1 \mathrm{~m}$ rise), 2 ( $0.2 \mathrm{~m}$ rise) and 3 ( $0.3 \mathrm{~m}$ rise), respectively. The profile after $28 \mathrm{~h}$ represents the shape after $7 \mathrm{~h}$ of waves at SLR 4 (0.4 m rise). The last profile shows the revetment at the end of SLR 4 .

As the water level changes, the crest retreats landward by a total of $0.9 \mathrm{~m}$ in 38 hours (Figure 3 ).

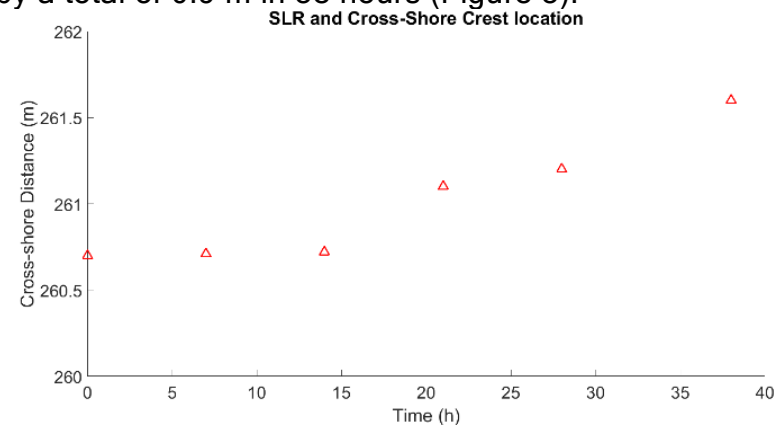

Figure 3: Cross-Shore location of the crest with time. The blue triangles mark the times showed in Figure 2.

In addition to the observed crest retreat, swash flows within the revetment lead to erosion of the sand underneath the structure, casing the base of the revetment to sink. While the base of the revetment sinks 
however, the crest level remains at approximately the same elevation throughout, indicating transport of cobbles from within the front face onto the crest to maintain crest height. However, in the meantime, the crest thickness increases significantly (Figure 4). At the end of the SLR tests, the crest is higher by $4 \mathrm{~cm}$ and thicker by $20 \mathrm{~cm}$ than at the beginning.

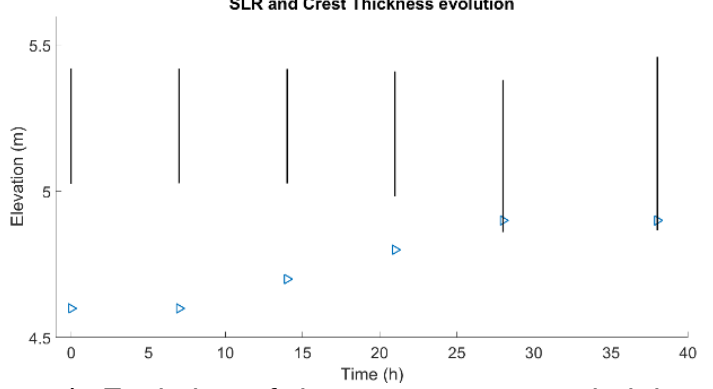

Figure 4: Evolution of the revetment crest height and thickness at each studied stage. The blue triangles represent the water level at each times showed in Figure 2. The black lines show the crest thickness at each time, delimited by the crest top at the top and the revetment and sand interface at the bottom.

The movement of individual cobbles was tracked using RFID. A total of 97 cobbles were tagged with Passive Integrated Transponders, each of them having a unique ID number. These instrumented cobbles were set in 3 three layers (sand interface layer, mid depth layer and surface layer) along the centerline of the revetment. With an antenna and a module reader, each cobble was detected and identified after each SLR. The analysis of the particles transport demonstrates that the probability for a cobble to be transported landward from their original position is significantly higher than seaward transport. This rolling over process prevents the revetment from sinking dramatically and eventually increases the crest height.

\section{COMPARISON OF THE BEACH WITH AND WITHOUT THE REVETMENT}

The full profile of the sand beach was measured before revetment construction and at the end of the experiment, and the elevation of the sand interface was monitored throughout. Before the revetment construction, a layer of $2.5 \mathrm{~m}^{3}$ of sand was removed from the active profile in order to build the revetment on a $1 / 15$ slope, at the desired location. This deficit of sand can be seen on figure 5,a. Despite this, the final aerial beach sand profile is higher with the revetment than without (figure $5, b$ ). On the other hand, the surf zone shows a lower profile with the revetment than without. The presence of the revetment-induced reflection and the non-eroded sand from the upper beach create this depletion on the terrace.

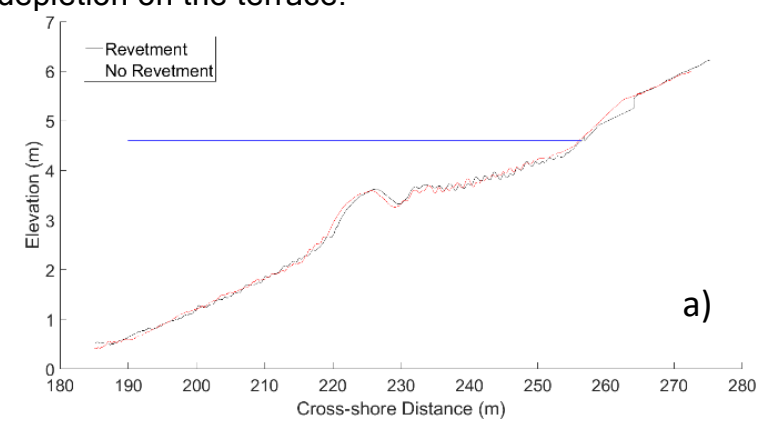

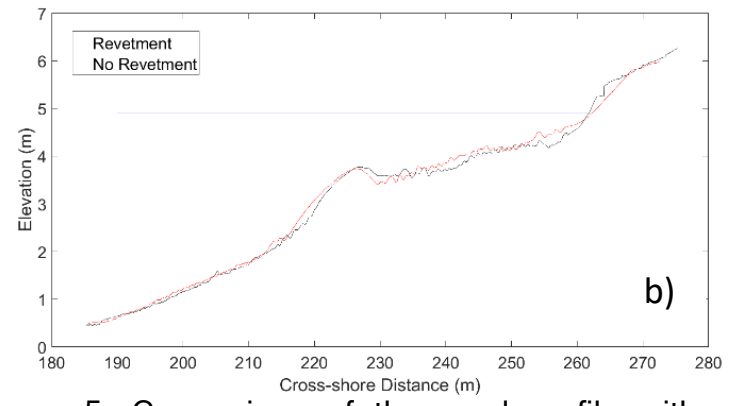

Figure 5: Comparison of the sand profile with and without the structure. The revetment has been removed on the black profile in order to display the underlying sand interface. a) after SLR 1 (7 h). b) after SRL 4 (38 h).

The sand bar volume or position does not appear to be significantly affected by the increased reflection from the revetment or the sand depletion. Overall, the percentage of sand on both sides of the shoreline relative to the total amount of sand is surprisingly similar for both cases (with and without the revetment) throughout the experiment.

The shoreline retreats further landward for the case where the beach is not protected by the revetment (Figure 6).

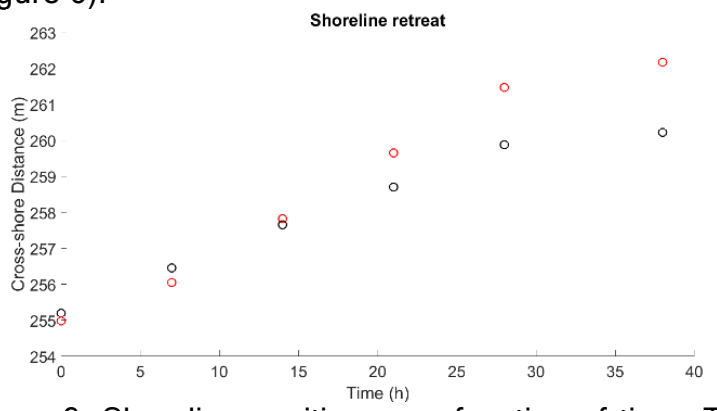

Figure 6: Shoreline position as a function of time. The black circles represent the shoreline with the revetment, and the red circles without.

\section{DISCUSSION}

Prior to SLR, the revetment provides overtopping protection to the hinterland. As the water level rises, the cobble berm starts rolling over, with cobbles being transported onto and over the crest during large runup events. This process causes the revetment to move landward and gain in elevation with SLR, while the crest thickens. The front slope of the revetment steepens significantly but the entire structure shows a resilient stability. The revetment stabilises the sand underneath and limit its erosion as well as slowing down the shoreline retreat. The surf zone is however, depleted in sand, while the sand bar volume and position remain similar. Thus, as long as accommodation space is available, the adapts to SLR, maintaining overtopping protection to the land behind and slowing beach and dune erosion and coastal recession.

\section{REFERENCES}

Komar, P. D. and Allan, J. C. (2009). "Design with Nature" Strategies for Shore Protection: Successes and Limitations of a Cobble Berm in an Oregon State Park. Presented at Puget Sound Shorelines and the Impacts of Armouring Workshop. 